\title{
EFL Adult Learners' Perceptions of Interaction and Their Attitudes Towards Learning English Online At Tesse. Io
}

\author{
Hieu Nguyen Thi Minh", Ha Nguyen Dinh Nhu \\ Ho Chi Minh City University of Technology (HUTECH)-Vietnam
}

*Corresponding Authors: Hieu Nguyen Thi Minh, Ho Chi Minh City University of Technology (HUTECH)-Vietnam

\begin{abstract}
The study aims to investigate students' perceptions of interaction and their attitudes towards learning English online at Tesse.io - an online learning and teaching website. Participants involved 96 adult learners in the pre-intermediate and intermediate level of English from online classes that the researcher is in charge of. The study adopted a sequential mixed method approach to data collection and analysis. Quantitative and qualitative data were gathered from the questionnaire and online interviews. The findings proved that students had a positive perception of interaction with teachers, other learners, and online course content. They valued the guidance and encouragement of teachers in classes. In addition, having students work in groups or with entire classes could enhance their interaction in online classrooms. Most students perceived positively about the course content which satisfied their needs and up-to-date. Regarding attitudes, students expressed positive opinions of feeling, behavior, and knowledge. They indicated an interest in learning in the online. Thus, students attended online classes more frequently and actively found more online classes to join. It was worth noticing that learning online meets students' expectations and their performance could be improved. Based on the findings of the study, recommendations for the stakeholders were included. Furthermore, it is expected that the study will shed light on the existing knowledge relating to the field of study.
\end{abstract}

Keywords: Perception, interaction, attitude, learning English, online learning

\section{INTRODUCTION}

Technology development since the 1990s has led to an increment in its usage in education and changes the way of learning and teaching. Recent development has heightened the growth of online learning. Online learning becomes a common alternative for adult learners since the learners cannot attend face-to-face classes regularly (Means, Bakia, \& Murphy, 2014). While the limited number of schools offer online courses, online programs are developing at a wide range in colleges and universities (Allen \& Seaman, 2017). According to Rovai, Wighting, and Lui (2005), there is almost no significant difference between technology versus face-to-face classroom settings, which does not make a difference in learning outcomes. Online learning is increasingly recognized in education research to find out appropriate answers for different research questions: What do learners think about online learning? What makes learners successful in an online learning environment? For those questions, Motargy and Boghikian (2010) argue that it seemly depends on learners' perceptions of interaction with instructors, other learners, and course content and their attitudes towards learning English online. Learners' perceptions of interaction and attitudes have caught the attention of researchers, educational institutions, and instructors. Richards and Rogers (2001) mention that teachers should attempt to determine learners' perceptions of interaction in a learning environment and students' attitudes by discussing directly with them. In online learning, learners' perceptions of interaction and learning attitudes are the primary concern.

In Vietnam, online learning becomes popular since it offers learners opportunities to gain skills, improve knowledge and life quality. Various efforts have been made to improve learners' English proficiency over the last decades (Hoang Yen Phuong, 2017). Besides, technological advancements are greatly influencing education (Long et al., 2013), educational institutions in Vietnam have offered a considerable number of online courses. Vietnam has increased the number of universities with distance education programs. However, online learning in Vietnam mainly stops at the level of using 
technology and has no pedagogical strategy specifically for higher education context (Long, Hao, \& Hunger, 2013). In addition, despite the importance of online learning and the wide scope of instructional practice in Vietnamese, few studies have examined online education in this country.

In general, based on the usefulness of the online English learning, the following research questions are formulated:

1. What are the students' perceptions of interaction with teachers, other learners, and online course content at Tesse?

2. What are the attitudes of adult learners towards learning English online?

\section{LITERATURE REVIEW}

Generally, there have been a great number of articles and research carried on the topics of learners' perceptions of interaction and learning attitudes towards online learning. The research of Alex (2015) at a border perspective at Walden University, America, emphasized the importance of research on learners' perceptions of interaction and their experiences in learning English. Research questions focused on how participants perceived the learning experiences in an online course and how they described their interaction. Results showed that participants rated interaction with the course content as the most important in learning online, followed by interaction with instructors and other students. In Turkey, Cemil and Saba (2018) researched 294 pre-school students at Middle East Technical University. The study preliminarily worked on learners' perception and their attitudes towards using technology in learning English. The result concluded that participants were interested in using smart devices in learning. In a similar vein, Falita and Faizah (2017) examined the attitudes and perceptions that affect learners' satisfaction and proficiency in private Islamic Boarding School, Indonesia. The result provided that learners' perceptions shed light on the motivation in using technology for language learning. The perception was a factor that determined learners' attitudes and proficiency in language learning. Positive perception would bring positive attitudes, motivation, and enthusiasm for learners to participate in learning activities. In the research of Yining and Chin-His (2019), the researchers explored the satisfaction of students when they learned in online classes. Satisfaction was considered as an outcome indicator for the success of online learning. The study was conducted among 226 high school students taking online language courses from 15 teachers at a Midwestern virtual school in the US. The research revealed that the learner-content interaction was the most significant predictor of students' satisfaction. For student-student interaction, the researchers stated that it significantly affected students' achievement, but not the most important thing that students consider in learning. Besides, the learner-teacher interaction in learning English online has a positive effect on students' motivation and their learning process. As being concerned, Bali and Liu (2018) conducted a study on the implication of online learning versus face-to-face learning in Taiwan. The study discussed learners' perceptions of course delivery and learners' interaction with social presence. The findings showed that online learning has some advantages despite perceived less social interaction than face-to-face classes. Besides, the study claimed that learners had positive attitudes in learning online and learned online because of convenient time and reasonable cost. A study held in Sunan Kalijaga Yogyakarta, Indonesia by Muhammad (2014) proposed that students were aware of the importance of the English language. However, their awareness did not reflect the attitude of the learners towards language learning. The study stated that there was no correlation between what students believe and their actual behaviors. In the research, Muhammad (2014) measured the motivational of the students towards the English language. As concerned, the researcher has defined that students were interested to learn a language with the motivation, encouragement, and when the learning process meet their expectation.

In Vietnam, many studies were conducted on learners' perceptions of interaction and learning attitudes towards learning in the online environment. The research of Nguyen Ngoc Vu (2016) reported that learners' perceptions affected attitudes, achievement, and performance in learning a language. The findings indicated that learners could access teachers through interactive videos. However, interaction in an online learning environment could not attract much learners' attention. The results revealed that although learners in online classes were still far from learning without direct interaction, they expressed positive attitudes towards online learning. Another finding of this study is 
while participants were interested in the course contents that help them learn visually and enrich online interaction, quite a few students are concerned about the lack of face-to-face interaction and group work that they get familiar with in the traditional English classes. In line with the literature review is the study of Trinh Thai Van Phuc (2016). The research focused on 444 undergraduate enrolled in the first semester in Ho Chi Minh City Open University. The learners' attitudes towards English concerning their learning motivation were examined. Besides, the researcher emphasized the importance of learners' perception of interaction since it related to language learning satisfaction and achievement. The results showed that students hold positive attitudes towards learning English. Besides, learners would achieve better in learning if they were extrinsically and intrinsically motivated to learn English through interaction with teachers, other learners, and course content.

The above-mentioned studies have been conducted in universities or big educational institutions such as colleges, private schools. Participants are chosen variously among different ages and English levels. However, few studies have addressed adult learners' perceptions of interaction and their attitudes towards learning online in an online learning website. There has been no research on relevant topics conducted at Tesse - an online learning website under the current study. Based on the literature review which provides important insights, the gap in examining adult learners' perception of interaction and their attitudes towards online learning still exists. To bridges this gap, the current study is desired to explore and investigate adult learners' perceptions of interaction and their attitudes towards learning English online at Tesse.

\section{METHODOLOGY}

\subsection{Research Setting and Participants}

The current study was conducted at Tesse.io - an online learning and teaching website in Ho Chi Minh City, Vietnam. Tesse is original as a technology company that organize online English classes. In Vietnam, Tesse has been established since November 2017. There are two main fields of operation in Tesse: developing of Electronic learning system (ELS) and organizing online English classes in Multidimensional Interactive Online Classroom (Virtual Classroom). Teese's mission is to connect the world knowledge into one system and to make it accessible to everyone. Tesse locates in Thich Quang Duc Street, Phu Nhuan, Ho Chi Minh City.

The participants of this study were 96 students who were learning in classes of the researcher. For more details, the demographic information of participants is shown in Table 1.

Table1. Demographic information of the participants

\begin{tabular}{|c|c|c|c|}
\hline \multirow{2}{*}{\multicolumn{2}{|c|}{ Content }} & \multicolumn{2}{|l|}{$\mathbf{N}=96$} \\
\hline & & FREQUENCY & PERCENT \\
\hline \multirow[t]{2}{*}{ 1. Gender } & Male & 73 & $76.0 \%$ \\
\hline & Female & 23 & $24.0 \%$ \\
\hline \multirow[t]{3}{*}{ 2. $\quad$ Time of learning English } & $<5$ years & 7 & $7.3 \%$ \\
\hline & $5-10$ years & 27 & $28.1 \%$ \\
\hline & $>10$ years & & $64.6 \%$ \\
\hline \multirow[t]{3}{*}{ 3. Time of learning at Tesse } & $<6$ months & 18 & 30.0 \\
\hline & 6 months to 1 year & 19 & 31.7 \\
\hline & $>1$ year & 23 & 38.3 \\
\hline \multirow{2}{*}{$\begin{array}{llll}4 . & \text { Learning in other English } \\
\text { centers } & & & \\
\end{array}$} & Yes & 89 & $92.3 \%$ \\
\hline & No & 7 & $7.3 \%$ \\
\hline \multirow{4}{*}{$\begin{array}{l}\text { 5. Online English courses taken } \\
\text { at Tesse }\end{array}$} & One course & 42 & $43.8 \%$ \\
\hline & 2- 3 courses & 23 & $24.0 \%$ \\
\hline & 4-6 courses & 13 & $13.4 \%$ \\
\hline & $>6$ courses & 18 & $18.8 \%$ \\
\hline \multirow[t]{2}{*}{ 6. $\quad$ Having smart devices } & Yes & 96 & $100 \%$ \\
\hline & No & 0 & $0 \%$ \\
\hline \multirow{2}{*}{$\begin{array}{l}\text { 7. Access to the internet for } \\
\text { learning online }\end{array}$} & Yes & 96 & $100 \%$ \\
\hline & No & 0 & $0 \%$ \\
\hline \multirow{3}{*}{$\begin{array}{llll}8 . & \text { Place of learning } & \text { English } \\
\text { online } & & & \\
\end{array}$} & At home & 87 & $90.6 \%$ \\
\hline & At the university & 0 & $0 \%$ \\
\hline & At the coffee shop & 3 & $3.12 \%$ \\
\hline
\end{tabular}


EFL Adult Learners' Perceptions of Interaction and Their Attitudes Towards Learning English Online At Tesse. Io

\begin{tabular}{|c|c|c|c|}
\hline \multirow[t]{3}{*}{ Content } & & \multicolumn{2}{|l|}{$N=96$} \\
\hline & & FREQUENCY & PERCENT \\
\hline & Other places & 6 & $6.25 \%$ \\
\hline
\end{tabular}

\subsection{Research Instruments}

\subsubsection{Questionnaire}

In this study, general questions on participants' personal information were presented before specific ones so that participants did not confuse when completing the questionnaires. From the outcome of the literature review, the researcher had found pre-existing instruments that were useful to measure key variables of the current study. Although using an existing questionnaire helped to save time and resources, the published questionnaire was not available in the language required for the respondents. To suit the research needs, the researcher adapted questions from the pre-existing studies in a similar research field. The questions in the questionnaire were in the form of Likert scale items ranked on 5 choices including "strongly disagree", "disagree", "neutral", "agree" and "strongly agree". Questionnaires delivered to participants were in Vietnamese and an English version was presented in the master thesis since there was a limitation in data collection due to the English levels of participants.

\subsubsection{Interview}

The online interviews were conducted with 10 adult learners volunteer to participate. The online interview lasted from 25 to 30 minutes. The online interviews were conducted in Vietnamese and translated into English to present in the master thesis. After the interviews, the researcher had sent each participant a copy of the interview transcript for them to review and confirm the information transcribed.

\subsection{Data Analysis}

The researcher used quantitative date descended from the questionnaires for learners to analyze by employing SPSS, and it was sure to examine the data of the questionnaires by using descriptive statistics. Meanwhile, qualitative data was derived from the information from the semi-structured interviews of the participants. The data from them particularly devoted deeper analysis for this study, and also provided connections between the participants' perceptions of interaction and attitudes towards learning English online.

\section{FINDINGS AND DISCUSSION}

\subsection{Findings}

\subsubsection{Students' Perception of Their Interaction with Teachers}

The following results relate to the assessment of student-teacher interaction. Perceptions of studentteacher interaction are reported through seven statements.

Table2. Descriptive Statistics and Percentage of respondents for each statement of interaction with teachers

\begin{tabular}{|c|c|c|c|c|c|c|c|c|}
\hline \multirow[b]{2}{*}{ Item } & \multirow[b]{2}{*}{ Content } & \multicolumn{7}{|c|}{$\mathrm{N}=96$} \\
\hline & & $1(\%)$ & $2(\%)$ & $3(\%)$ & $4(\%)$ & $5(\%)$ & $\mathbf{M}$ & SD \\
\hline 9 & $\begin{array}{l}\text { Teachers are available to assist me in } \\
\text { online classes. }\end{array}$ & 1.0 & 14.6 & 30.2 & 49.0 & 5.2 & 3.43 & 0.84 \\
\hline 10 & $\begin{array}{l}\text { The teaching method of teachers } \\
\text { improve my learning performance. }\end{array}$ & 0 & 6.3 & 18.8 & 68.8 & 6.3 & 3.75 & 0.67 \\
\hline 11 & $\begin{array}{l}\text { The teachers give opportunities for me } \\
\text { to express my view. }\end{array}$ & 2.1 & 4.2 & 21.9 & 52.1 & 19.8 & 3.83 & 0.87 \\
\hline 12 & $\begin{array}{l}\text { When I have a difficulty in learning, } \\
\text { teachers provide effective guidance }\end{array}$ & 2.1 & 5.2 & 16.7 & 55.2 & 20.8 & 3.88 & 0.87 \\
\hline 13 & $\begin{array}{l}\text { Teachers always encourage students to } \\
\text { learn hard. }\end{array}$ & 2.1 & 2.1 & 21.9 & 54.2 & 19.8 & 3.87 & 0.82 \\
\hline 14 & $\begin{array}{l}\text { The teachers provide me with the } \\
\text { guidance to self-study effectively at } \\
\text { home. }\end{array}$ & 0 & 9.4 & 31.3 & 46.9 & 12.5 & 3.63 & 0.82 \\
\hline 15 & The instruction provided by teachers on & 2.1 & 7.3 & 24.0 & 51.0 & 15.6 & 3.71 & 0.89 \\
\hline
\end{tabular}


EFL Adult Learners' Perceptions of Interaction and Their Attitudes Towards Learning English Online At Tesse. Io

\begin{tabular}{|l|l|l|l|l|l|l|l|l|}
\hline & \multicolumn{5}{|c|}{$\mathbf{N = 9 6}$} & \multicolumn{7}{|c|}{} \\
\hline Item & Content & $\mathbf{1}(\boldsymbol{\%})$ & $\mathbf{2}(\boldsymbol{\%})$ & $\mathbf{3 ( \% )}$ & $\mathbf{4}(\boldsymbol{\%})$ & $\mathbf{5}(\boldsymbol{\%})$ & $\mathbf{M}$ & SD \\
\hline & the platform is easy to follow. & & & & & & & \\
\hline
\end{tabular}

As can be seen from Table 2, all items have the mean score ranging over 3, indicating that students agree that their interaction with teachers is positive. The results become more obvious when analyzing the mean scores and frequency. Item 12 rates the highest with mean of $3.88(\mathrm{SD}=0.87)$, in which $55.2 \%$ of the students agreed that the teachers provided effective guidance when they had difficulty in learning. Aligning with quantitative data, qualitative data indicated that 10 learners $(100 \%)$ expressed a positive view of interaction with teachers. Some particular opinions of students are presented below:

"I feel free to talk to my teachers, I can easily share what I have problems in learning." (Student 1);

"The good thing is when we cannot answer the teachers, they are always patient and motivate us to speak out." (Student 2)

Following the range is item 13 with the mean score of 3.87 ( $\mathrm{SD}=0.82)$, in which more than $54.2 \%$ of respondents proved that teachers always encourage them to learn hard. This result goes in line with the responses of the online interviews when the students expressed the opinion of teachers' encouragement:

"I like the way they give instruction and encourage us to raise question. I am a little shy at the first time by after some classes, I do not hesitate to ask for their help." (Student 1); "I think student-teacher interaction benefits me. As I can communicate with teachers, they give me advice on my weakness and strength." (Student 6)

Another worth noticing result is $52.1 \%$ of respondents agreed that teachers gave them chances to express opinions in online classroom (item $11, \mathrm{M}=3.83, \mathrm{SD}=0.87$ ). In terms of teachers' instruction, $51 \%$ of respondents agreed that the instruction provided on the platform was easy to follow (item 15, $\mathrm{M}=3.71, \mathrm{SD}=0.89$ ). Beside, more than $68 \%$ of students agreed that the teaching method of teachers approve their learning performance. Aligning with quantitative data, qualitative data indicated that:

"In online classes, teachers do not always talk to us, they give us time to talk with other learners. That encourages me a lot since I feel free to share my experiences" (Student 4); "I can participate in class discussion and give my opinions." (Student 9)

In addition, another point here is while students valued the teachers' assistance, teaching method, and encouragement, a part of them $(46.9 \%)$ had a neutral opinion on the guidance for self-study from teachers (item 14, $\mathrm{M}=3.63, \mathrm{SD}=0.89$ ). The lowest mean belongs to item $9(\mathrm{M}=3.43, \mathrm{SD}=0.84$ ), suggesting that most of the students agreed that teachers were available to assist them in online classes.

\subsubsection{Students' Perception of Interaction with Other Learners}

In an attempt to explore the students' perception of interaction with learners, seven statements were allotted to address this component. As shown in Table 3, all items from 16 to 22 have a mean score ranging over 3.5 .

Table3. Descriptive Statistics and Percentage of respondents for each statements of their interaction with other learners in online English classes.

\begin{tabular}{|l|l|l|l|l|l|l|l|l|}
\hline & \multicolumn{5}{|c|}{$\mathbf{N = 9 6}$} \\
\hline Item & Content & $\mathbf{1}(\mathbf{\%})$ & $\mathbf{2}(\mathbf{\%})$ & $\mathbf{3}(\mathbf{\%})$ & $\mathbf{4}(\mathbf{\%})$ & $\mathbf{5}(\mathbf{\%})$ & $\mathbf{M}$ & SD \\
\hline 16 & $\begin{array}{l}\text { I have many opportunities to interact } \\
\text { with classmates. }\end{array}$ & 3.1 & 8.3 & 36.5 & 45.8 & 6.3 & 3.44 & 0.86 \\
\hline 17 & $\begin{array}{l}\text { I feel encouraged to interact with other } \\
\text { students. }\end{array}$ & 3.1 & 6.3 & 38.5 & 45.8 & 6.3 & 3.46 & 0.83 \\
\hline 18 & $\begin{array}{l}\text { I can participate in an online discussion } \\
\text { with the entire class. }\end{array}$ & 5.2 & 5.2 & 24.0 & 52.1 & 13.5 & 3.64 & 0.96 \\
\hline 19 & $\begin{array}{l}\text { I can take part in small group } \\
\text { discussions online. }\end{array}$ & 4.2 & 4.2 & 24.0 & 54.2 & 13.5 & 3.69 & 0.91 \\
\hline 20 & $\begin{array}{l}\text { I can communicate with other learners } \\
\text { about different topics. }\end{array}$ & 2.1 & 4.2 & 20.8 & 65.6 & 7.3 & 3.72 & 0.75 \\
\hline 21 & \begin{tabular}{l} 
I exchange resources (such as links or \\
\hline
\end{tabular} & 2.1 & 11.5 & 37.5 & 34.4 & 14.6 & 3.48 & 0.95 \\
\hline
\end{tabular}

International Journal on Studies in English Language and Literature (IJSELL) 
EFL Adult Learners' Perceptions of Interaction and Their Attitudes Towards Learning English Online At Tesse. Io

\begin{tabular}{|l|l|l|l|l|l|l|l|l|}
\hline & \multicolumn{9}{|c|}{ N=96 } \\
\hline Item & Content & $\mathbf{1}(\%)$ & $\mathbf{2 ( \% )}$ & $\mathbf{3 ( \% )}$ & $\mathbf{4}(\boldsymbol{\%})$ & $\mathbf{5}(\boldsymbol{\%})$ & $\mathbf{M}$ & SD \\
\hline & documents) with classmates. & & & & & & & \\
\hline 22 & $\begin{array}{l}\text { I can contribute personal experiences } \\
\text { related to course content. }\end{array}$ & 1.0 & 4.2 & 33.3 & 47.9 & 13.5 & 3.69 & 0.80 \\
\hline
\end{tabular}

In investigating the communication in online courses, students were asked if they communicated with other students about different topics (item $20, \mathrm{M}=3.72, \mathrm{SD}=0.75$ ). Results show that a great majority of students expressed strong agreement on communication with other learners. The two representative comments in interviews are presented follow:

"I interact by typing in the chat box to discuss a topic or just to write down what I hear from their conversation. (Student 3); "I enjoy learning the language on my own. However, teachers encourage us to join in conversation among students in online classes." (Student 8)

More than $54 \%$ of students agreed that they took part in small group discussions (item 19, M=3.69, $\mathrm{SD}=0.91$. Besides, $52.1 \%$ of students agreed that they could take part in online discussions with the entire class (item $18, \mathrm{M}=3.64, \mathrm{SD}=0.96$ ). The results became clear when $38.5 \%$ of students presented a neutral opinion and more than $45 \%$ of students agreed that they feel the encouragement to interact with other students in online classes (item 17, M=3.75, SD=0.67). Some of the responses are stated below:

"I think the interaction with other learners is promoted by teachers and brings me motivation. I can feel a connection with other learners." (Student 1); "There are group or class discussions in online classes. The atmosphere for a lively discussion." (Student 3)

When responses to the statement "I can contribute personal experiences related to course content" are analyzed, $47.9 \%$ of students agreed that they could contribute their personal experiences related to the course content. $37.5 \%$ of students had a neutral opinion and $34.4 \%$ agreed that they could exchange resources with classmates on online classes. The responses by two participants represented the general opinion in this study:

"In the online classes, I have many chances to interact and exchange knowledge with other learners. They are willing to share their opinions with me." (Student 6); "When I engage in dialogue with other learners in online classes, I can find new words and increase my vocabulary." (Student 9)

The lowest mean belongs the statement "I have many opportunities to interact with classmates" with $\mathrm{M}=3.44$ ( $\mathrm{SD}=0.86$ ). This result is explained in the online interviews through some opinions as below:

"I can interact with other learners. However, there are many students in the online classroom and the learning time is limited, I just can sometimes practice speaking with them." (Student 2)

\subsubsection{Students' Perception of Interaction with Course Content}

As illustrated in Table 4, the mean score of statements about student-content interaction ranges from 3.28 to 3.74 , which means generally the students' perception of interaction with the online course content is positive. The results become clear with the analysis of the items in the category.

Table4. Descriptive Statistics and Percentage of respondents for each statements of their interaction with course content

\begin{tabular}{|l|l|l|l|l|l|l|l|l|}
\hline & \multicolumn{9}{|c|}{$\mathbf{N = 9 6}$} \\
\hline Item & Content & $\mathbf{1}(\mathbf{\%})$ & $\mathbf{2}(\boldsymbol{\%})$ & $\mathbf{3}(\mathbf{\%})$ & $\mathbf{4}(\mathbf{\%})$ & $\mathbf{5}(\mathbf{\%})$ & $\mathbf{M}$ & SD \\
\hline 23 & The course content fits my needs. & 2.1 & 6.3 & 24.0 & 51.0 & 16.7 & 3.74 & 0.89 \\
\hline 24 & The course content is up-to-date. & 1.0 & 7.3 & 31.3 & 40.6 & 19.8 & 3.71 & 0.91 \\
\hline 25 & $\begin{array}{l}\text { I can easily interact with the course } \\
\text { content through a variety of tools. }\end{array}$ & 1.0 & 9.4 & 31.3 & 42.7 & 15.6 & 3.62 & 0.90 \\
\hline 26 & $\begin{array}{l}\text { I prefer to learn from the online } \\
\text { course materials rather than the } \\
\text { traditional one. }\end{array}$ & 5.2 & 9.4 & 42.7 & 37.5 & 5.2 & 3.28 & 0.90 \\
\hline 27 & $\begin{array}{l}\text { The course allow me more flexibility } \\
\text { in my daily activities. }\end{array}$ & 5.2 & 4.2 & 22.9 & 57.3 & 10.4 & 3.64 & 0.92 \\
\hline 28 & \begin{tabular}{l} 
The course materials are placed in \\
\hline
\end{tabular} & 4.2 & 9.4 & 32.3 & 45.8 & 8.3 & 3.45 & 0.93 \\
\hline
\end{tabular}


EFL Adult Learners' Perceptions of Interaction and Their Attitudes Towards Learning English Online At Tesse. Io

\begin{tabular}{|c|c|c|c|c|c|c|c|c|}
\hline & & \multicolumn{7}{|c|}{$\mathrm{N}=96$} \\
\hline Item & Content & $1(\%)$ & $2(\%)$ & $3(\%)$ & $4(\%)$ & $5(\%)$ & $\mathbf{M}$ & SD \\
\hline & $\begin{array}{l}\text { website in a timely manner after } \\
\text { finishing online classes. }\end{array}$ & & & & & & & \\
\hline
\end{tabular}

The most striking finding of this part the majority of the students $(51 \%)$ proved that the online course content at Tesse fits their needs $(\mathrm{M}=3.74, \mathrm{SD}=0.89)$. Besides, when responses were asked whether "The course content is up-to-date", more than $31 \%$ of them have a neutral opinion, $40.6 \%$ of them agreed and $19.8 \%$ of them strongly agreed with the statement. Data from the interviews reflected the same view when students shared that the course content meet their requirement. The below opinions support the result from online survey:

"... In practice, the course content is quite adequate. It is designed logically and suits my level." (Student 2); "I believe the online course content at Tesse fits my need..." (Student 9)

Besides, when it comes to the flexibility of online courses, $57.3 \%$ of students agreed that the online course allowed more flexibility in daily activities $(\mathrm{M}=3.64, \mathrm{SD}=0.92)$. The analysis of the responses showed that $32.3 \%$ of students had a neutral opinion and $45.8 \%$ agreed that the course materials were placed on the website in a timely manner after finishing online classes $(\mathrm{M}=3.45, \mathrm{SD}=0.93)$. This finding is consistent with data from the interviews in which one student stated that:

"I can easily review the course content before joining any courses. I can also download the materials and handouts of the lessons after the classes." (Student 1)

The majority of the students (31.3\%) had a neutral opinion and $42.7 \%$ agreed that they easily interacted with the course content through a variety of tools. In terms of comparison between online learning materials and traditional one, $42.7 \%$ of students had a neutral opinion and $37.5 \%$ agreed on the statement "I prefer to learn from the online course materials rather than the traditional one". These findings were aligned with data from the interviews when students' opinion supported the results of questionnaires:

".. I can download the content in PDF files onto my smart devices to learn wherever I want.

Tesse has lessons for learners from beginners like me.” (Student 5)

\subsubsection{Students' Affective Aspect of Attitudes}

Analysis results in Table 5 show that in general, the participants like to learn English online and they have positive emotions of effective attitudes $(\mathrm{M}=3.58, \mathrm{SD}=0.64)$. The 6 items in the questionnaire aim to assess whether the student like learning online, the reasons and the effectiveness of learning English online.

Table5. Descriptive Statistics and Percentage of respondents for each statements of Affective Aspect of Attitudes

\begin{tabular}{|l|l|l|l|l|l|l|l|l|}
\hline & \multicolumn{7}{|c|}{$\mathbf{N = 9 6}$} \\
\hline Item & Content & $\mathbf{1}(\mathbf{\%})$ & $\mathbf{2 ( \% )}$ & $\mathbf{3}(\mathbf{\%})$ & $\mathbf{4}(\boldsymbol{\%})$ & $\mathbf{5}(\mathbf{\%})$ & $\mathbf{M}$ & SD \\
\hline 29 & $\begin{array}{l}\text { I am interested in learning English } \\
\text { online. }\end{array}$ & 2.1 & 4.2 & 32.3 & 42.7 & 18.8 & 3.72 & 0.89 \\
\hline 30 & $\begin{array}{l}\text { I feel more confident when I practice } \\
\text { using English in online classes. }\end{array}$ & 3.1 & 13.5 & 34.4 & 40.6 & 8.3 & 3.38 & 0.93 \\
\hline 31 & $\begin{array}{l}\text { I am comfortable with the usage of } \\
\text { smart devices to learn English online. }\end{array}$ & 2.1 & 8.3 & 32.3 & 45.8 & 11.5 & 3.56 & 0.88 \\
\hline 32 & $\begin{array}{l}\text { It is convenient to access learning } \\
\text { materials from the course website. }\end{array}$ & 1.0 & 8.3 & 29.2 & 55.2 & 6.3 & 3.57 & 0.78 \\
\hline 33 & $\begin{array}{l}\text { I benefit from feedbacks of teacher } \\
\text { when learning online. }\end{array}$ & 1.0 & 9.4 & 33.3 & 44.8 & 11.5 & 3.56 & 0.86 \\
\hline 34 & $\begin{array}{l}\text { Learning English online meets my } \\
\text { expectations. }\end{array}$ & 1.0 & 8.3 & 24.0 & 56.3 & 10.4 & 3.67 & 0.82 \\
\hline
\end{tabular}

When being asked whether the students are interested in learning English online, more than $42.7 \%$ of them agreed with the statement. This statement obtained the first rank with $\mathrm{M}=3.72, \mathrm{SD}=0.89$. Results from the interview also reflected the same view when one of the participants indicated that:

"..I am interested in English online classes. I feel the courses is created based on students' interests, request, and areas that we need to improve. I think the online classes are interesting to attract our attention..." (Student 4) 
The reasons for the positive attitudes are presented in item 30, 21, and 32. Most students (40.6\%) posited that they felt more confident when practicing English in online classes (item 30, $\mathrm{M}=3.38, \mathrm{SD}=0.93$ ). Besides, they were comfortable when using smart devices to join online classes (item 31, M=3.56, $\mathrm{SD}=0.88$ ). One reason that students are interested in learning English online as it is convenient to access learning materials (item $32, \mathrm{M}=3.57, \mathrm{SD}=0.78$ ). More than $55 \%$ of students agreed with the statement "It is convenient to access learning materials from the course website". These findings were consistent with data from the interview when one student shared their opinions as below:

“...Learning English in online classes is comfortable, especially when I can learn by smartphone and I can join the classes anytime at my place.” (Student 3 )

Another significant point is that students proved the benefit of teachers' feedbacks in online English classes (item 33, M=3,56, SD=0.86). In fact, more than $44 \%$ of respondents showed their agreement on this statement. Besides, more than 56\% of students agreed that learning English online meets their expectations (Item 34, M=3.67, SD=0.82). To demonstrate the views of students regarding expectations when learning English online, the researcher had asked the relevant questions and one student presented their opinion as followings:

"With feedback and useful advice from the teachers, I know more about the learning method." (Student 2)

\subsubsection{Students' Behavioral Aspect of Attitudes}

As mentioned in the literature reviews, there is a strong connection between attitude and behavior. Hence, measuring the behavioral aspect of attitudes has an important role in understanding students' behavior (Kara, 2009). In analysis of behavioral aspect of attitudes, students expressed the positive attitudes $(\mathrm{M}=3.69, \mathrm{SD}=0.48)$ and showed a great probability of accepting online English learning.

Table6. Descriptive Statistics and Percentage of respondents for each statements of Behavioural Aspect of Attitudes

\begin{tabular}{|l|l|l|l|l|l|l|l|l|}
\hline & \multicolumn{5}{|c|}{ SD=96 } & \multicolumn{5}{|c|}{} \\
\hline Item & Content & $\mathbf{1}(\boldsymbol{\%})$ & $\mathbf{2}(\mathbf{\%})$ & $\mathbf{3}(\mathbf{\%})$ & $\mathbf{4}(\mathbf{\%})$ & $\mathbf{5}(\mathbf{\%})$ & $\mathbf{M}$ & SD \\
\hline 35 & $\begin{array}{l}\text { I attend online courses more frequently } \\
\text { because it is convenient to learn at my } \\
\text { place. }\end{array}$ & 0 & 2.1 & 16.7 & 64.6 & 16.7 & 3.96 & 0.65 \\
\hline 36 & $\begin{array}{l}\text { I find other online English courses to } \\
\text { attend. }\end{array}$ & 0 & 5.2 & 18.8 & 60.4 & 15.6 & 3.86 & 0.74 \\
\hline 37 & $\begin{array}{l}\text { I proactively practice English more in } \\
\text { my online classes. }\end{array}$ & 0 & 4.2 & 16.2 & 64.6 & 16.7 & 3.94 & 0.69 \\
\hline 38 & $\begin{array}{l}\text { I am able to make myself to pay } \\
\text { attention during the class when studying } \\
\text { English online. }\end{array}$ & 1.0 & 14.6 & 32.3 & 47.9 & 4.2 & 3.40 & 0.83 \\
\hline 39 & $\begin{array}{l}\text { I pay much attention to learning English } \\
\text { online. }\end{array}$ & 0 & 15.6 & 30.2 & 51.0 & 3.1 & 3.42 & 0.79 \\
\hline 40 & $\begin{array}{l}\text { I spend time to do assignment after } \\
\text { online classes. }\end{array}$ & 0 & 11.5 & 33.3 & 51.0 & 4.2 & 3.48 & 0.75 \\
\hline
\end{tabular}

As shown in Table 6, students gave high credit in terms of attending online classes. There are more than $64 \%$ of students expressed that they attend online courses more frequently because of its convenience. Statement 35 represents the highest mean score of 3.96 with $\mathrm{SD}=0.65$. The below opinions in interviews prove for the result of statistic analysis:

"It is suitable for my working schedule. I can choose times that suit my working schedule. It is also easy to learn with a computer or a smart phone." (Student 1)

The results revealed that $63 \%$ of the students proactively practice English more in online classes, presenting the second-highest mean score of $3.94(\mathrm{SD}=0.69)$. With the item "I find other online English courses to attend", students show great positive opinion as more than $60 \%$ of them agree with the statement. This result was reflected in the interview when a student demonstrated the opinion as below: 
"I am more confident in communicating with English. I express my opinions more in online classes. Learning in an online environment offers me the chance to practice frequently without hesitation." (Student 1)

\subsubsection{Students' cognitive aspect of attitudes}

On the basis, the cognitive aspect represents the highest mean score of students' attitudes towards learning English online ( $\mathrm{M}=4.02, \mathrm{SD}=0.44)$. It appears that the majority of the respondents show positive the cognitive aspect of attitudes. Table 7 sets out a clearer picture of cognitive aspect of students' attitudes.

Table7. Descriptive Statistics and Percentage of respondents for each statements of Cognitive Aspect of Attitudes

\begin{tabular}{|c|c|c|c|c|c|c|c|c|}
\hline & & \multicolumn{7}{|c|}{$\mathrm{N}=96$} \\
\hline Item & Content & $1(\%)$ & $2(\%)$ & $3(\%)$ & $4(\%)$ & $5(\%)$ & M & SD \\
\hline 41 & $\begin{array}{l}\text { Since I learned English online, my } \\
\text { performance has been improved. }\end{array}$ & 0 & 1.0 & 8.3 & 66.7 & 24.0 & 4.12 & 0.64 \\
\hline 42 & $\begin{array}{l}\text { My attitudes towards learning English has } \\
\text { changed since I joined online classes. }\end{array}$ & 0 & 2.1 & 13.5 & 70.8 & 13.5 & 3.96 & 0.60 \\
\hline 43 & $\begin{array}{l}\text { Student-teacher interaction meets my } \\
\text { expectations. }\end{array}$ & 0 & 0 & 13.5 & 67.7 & 18.8 & 4.05 & 0.57 \\
\hline 44 & $\begin{array}{l}\text { Student-student interaction meets my } \\
\text { expectations. }\end{array}$ & 0 & 1.0 & 25.0 & 55.2 & 18.8 & 3.92 & 0.69 \\
\hline 45 & $\begin{array}{l}\text { Student-content interaction meets my } \\
\text { expectations. }\end{array}$ & 0 & 1.0 & 20.8 & 63.5 & 14.6 & 3.92 & 0.63 \\
\hline 46 & $\begin{array}{l}\text { I look forward to studying English online } \\
\text { more in the future. }\end{array}$ & 0 & 0 & 5.2 & 72.9 & 21.9 & 4.17 & 0.50 \\
\hline
\end{tabular}

A positive result was $66.7 \%$ of students agreed that their performance had been improved since they learned English online (item 41, M=4.12, SD=0.64). Apart from that, a considered part of students $(24 \%)$ strongly agreed, around $8 \%$ of students had a neutral opinion and almost no student expressed negative attitudes about statement 41 "Since I learned English online, my performance has been improved.". The same was expressed in the interview when one participant said:

"In online classes, I can receive instant feedbacks from teachers. I have to say that my performance has been improved after joining online classes." (Student 3)

Most of the respondents $(71.1 \%)$ indicated that their attitude had been changed since they joined online classes $(\mathrm{M}=3.96, \mathrm{SD}=0.60)$. In agreement with those who answered in the questionnaire, an interviewee expressed their opinions as below:

" In the beginning, my speaking and listening become better. I can hear and understand teachers and other learners say, then I can speak up. I think that learning online is the time for us to practice speaking, but it appears that I can improve both writing and speaking." (Student 4)

It is quite interesting to observe whether the interaction in the online learning environment meets the students' expectations. More than haft of students agreed that the student-teacher interaction, studentstudent interaction, student-content interaction meet their expectations ( $M=4.05$, 3.92, and 3.92, respectively). The findings reinforce the research instruments' validity and reliability. To deeply understand the students' opinions, 10 respondents were asked whether the interaction in the online learning environment meet their expectations. Some particular opinions of the respondents are presented below:

- Student-teacher interaction:

"Teachers provide me a comfortable learning environment so that I can ask for their help whenever I have any difficulty in learning English. Teachers in Tesse always support me that way." (Student 1)

- Student-student interaction:

"Yes, I learn with classmates working in different fields so that I can exchange and communicate with them about different topics." (Student 2); "I have time to work in group in online classes. I consider it is major to develop myself if I can communicate with my fellow." (Student 5). 
- Student-content interaction:

"The course content is clearly outlined so that I can easily image the course." (Student 1);" As I am a worker and I don't have much time, I consider the course content suitable with my job and the learning time fits my working schedule." (Student 2)

The above results relate to the noticing finding that more than $72 \%$ of the students looked forward to studying English online more in the future $(\mathrm{M}=4.17, \mathrm{SD}=0.50)$. This result was clearly shown when there are nine of ten students agreed that they would continue to join online English classes in the online interviews. In agreement with those who answered the questionnaires, a student presented the opinion as below:

"..The important thing is how effective I can learn English, not about whether it is online classes or traditional English classes.” (Student 10)

\subsection{Discussion}

The results proved that students perceived their interaction in the online learning environment positively. Among the learners' interaction with teachers, other learners, and course content, the students emphasized the value of interaction with teachers. This result did not go in line with the previous study of Alex (2015). He shows that participants rate interaction with the course content as the most important in learning online, followed by interaction with instructors, and student-student interaction. The result of the current study goes in line with the previous study of Nguyen $\mathrm{Ngoc} \mathrm{Vu}$ (2016). According to the researcher, the development of technology offers students chances to learn English. Online learning gives students opportunities to interact and collaborate in classes. Nguyen Ngoc Vu (2016) states that students do not usually contribute to traditional classroom discussions for certain reasons. However, in online English classes, they have the opportunity to express ideas without hesitation. Besides, they join online classes with comfortable attitude to express their ideas more freely and actively. In addition, it was concluded that student-teacher, student-student, studentcontent have a positive effect on students' motivation and their learning process. This result goes in line with the study by Yining and Chin-His (2019). They found that the students expressed great willingness to participate in online English courses as they were encouraged and motivated by teachers. Yining and Chin-His (2019) state that the interaction significantly affects students' motivation, but not the most important thing that students consider in learning. The learner-content interaction leads to positive emotional and motivational outcomes. However, the researchers indicate that the learner-content interaction is the most significant predictor of students' satisfaction, which differs from the results of this study.

With respect to the students' attitudes towards learning English online, the findings revealed that their attitudes were positive. Interestingly, most of the students associated the benefits of learning English online. Their attitudes are caused by the convenience and the comfort of using smart devices to learn in online classes. These results are supported by the study of Cemil and Saba (2018).In the previous research, the researcher revealed that most of the students indicated the comfort of using the smart devices to learn online and the convenience of accessing materials from the course website. Together with the positive in students' emotions (the affective aspect of attitudes), their behavioral and cognitive aspect of attitudes were positive as students' feelings and emotions determine the behavior and attitudes towards something. This result is similar to the study of Falita and Faizah (2017) that there is a strong positive correlation between the students' perception of and their attitude towards learning the language. When the students' have a positive perception of their interaction in learning, they are bound to have a positive attitude towards learning thelanguage. The more favorable their perception of interaction in online learning English, the more positive their attitude towards the learning process. Falita and Faizah (2017) observed and measured the students' attitudes and perceptions towards English Language learning and their English language proficiency. According to the researchers, positive attitudes bring more motivated and enthusiastic students to attend classes and participate in learning activities. They should be more creative and concentrate on online classes. In the research of Falita and Faizah (2017), most students expressed that they achieved better performance in learning English online. As learning English online meet students' expectation, they look forward to studying English online more in the future. 


\section{CONCLUSION AND IMPLICATIONS}

The results of this study indicated that both students' interaction and their attitudes impact learners' satisfaction and success in an online learning environment. Participants would like to see improved performance when learning in online English classes. Although the results revealed that students' perception of interaction and their attitude were positive, they would like teachers to assist more in the classes as well as spend more time for them to interact with classmates. Besides, the online course materials should be improved to attract them.

The findings suggested several courses of action for learners, teachers and administrators of the center. First of all, learners should spend more time to self-study at home before and after the class, take into account is that learning English online is a part of the learning process. What is more, students should try to apply their knowledge of English in daily work or study. To the teachers, it is important to interact with the students in the online classroom without leaving them to their own devices most of the time. The teachers should stay a few minutes afterward to talk one-on-one with a student who needs extra support. For the administrators, they should take into account to provide more effective online classes for learners. They should further support students by providing them more easy way access to resources or learning materials.

\section{REFERENCES}

[1] Allen, I. E. \& Seaman, J. (2017). Digital learning compass: Distance education enrolment Report 2017. Babson Survey Research Group. Retrieved from https://onlinelearningsurvey.com/reports/digtiallearning compassenrollment2017.pdf

[2] Alex, A. N. (2015). Students' learning experiences and perception of online course content and interaction. Walden University. Retried from https://scholarworks.waldenu.edu/dissertations/188/

[3] Bali, S. \& Liu M. C. (2018). Students' perceptions towards online learning and face-to-face learning courses. Journal of Physics Conference Series. Retrieved from https://www.researchgate.net/publication/ 329379022_Students'_perceptions_toward_online_learning_and_face-to-face_learning_courses

[4] Baker, C. (1992). Attitudes and Language. Clevedon, England: Multilingual Matters.

[5] Cemil, I. \& Saba, O. (2018). Attitude towards Mobile Learning in English Language Education. Education Sciences. Retrieved from https://www.researchgate.net/publication/327567461_Attitude_towards_Mobile _Learning_in_English_Language_Education

[6] Falita, G. J. \& Faizah, I. (2017). EFL students' attitudes and perceptions towards English Language learning and their English language proficiency: A study from Assa'adah Islamic Boarding School, Indonesia. Journal of Education and Learning, 11(3), 219-228.

[7] Long, L., Hao, T., \& Hunger, A. (2013). Developing an active collaborative e-learning framework for Vietnam's higher education context. Proceedings of the International Conference on e-Learning, 240-249.

[8] Means, B., Bakia, M., \& Murphy, R. (2014). Learning online: What research tells us about whether, when, and how (1st ed.). New York, NY: Routledge.

[9] Motargy, Y., \& Boghikian, W. S. (2010). A longitudinal comparative study of student perceptions in online education. Interdisciplinary Journal of E-Learning and Learning Objects, 6(10), 23-43. Retrieved from http://www.ijello.org/Volume6/IJELLOv6p023-044Mortagy684.pdf

[10] Muhammad, K. (2014). The Language Attitude of the Students of English Department Uin Sunan Kalijaga Towards English. English department of faculty adab and cultural State Islamic university Sunan Kalijaga Yogyakarta.

[11] Nguyen, Ngoc Vu (2016). An investigation of Vietnamese students' learning styles in online language learning. Journal of Science of HCM City University of Education, 1(9).

[12] Padwick, A. (2010). Attitudes towards English and Varieties of English in Globalizing India. University ofGroningen. Newcastle, England.

[13] Phuong, Hoang Yen (2017). The people of Vietnam: Their voices and lived experiences (Countries and cultures of the world). Nova Science Publisher, Inc.

[14] Richards, J. C. \& Rogers, T.S. (2001). Approaches and methods in language teaching. New York, NY: Cambridge University Press.

[15] Rovai, A. P., Wighting, M. J., \& Liu, J. (2005). School Climate: Sense of classroom and school communities in online and on-campus higher education courses. Quarterly Review of Distance Education, 6(4), 361-374. 
[16] Trinh Thai Van, Phuc (2016). Language attitudes of Vietnamese undergraduates towards English: An investigation at school of advanced studies of Ho Chi Minh City Open University. Journal of Science Ho Chi Minh City Open University, 19(3), 84-100.

[17] Yining, Z. \& Chin-His, L. (2019). Student interaction and the role of the teacher in a state virtual high school: what predicts online leaning satisfaction? Technology Pedagogy and Education, 29 (1), 57-71.

\section{AUTHORS' BIOGRAPHIES}

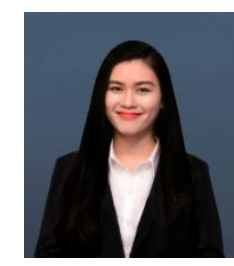

Ms. HieuNguyen Thi Minh, is currently a master student in Ho Chi Minh City University of Technology (HUTECH) - Vietnam. She has had over two years in teaching English skills to non-English majors. Her academic areas of interest mostly lie in technology in language teaching and English teaching methodologies.

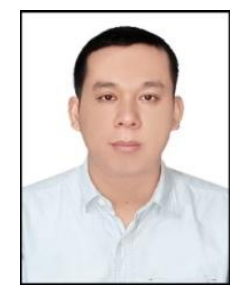

Mr. Ha Nguyen Dinh Nhu, is currently a full-time lecturer of English at Ho Chi Minh City University of Technology (HUTECH) - Vietnam. In addition, he is studying for a Doctorate in Education at Ho Chi Minh City University of Technology and Education.

Citation: Hieu Nguyen Thi Minh, Ha Nguyen Dinh Nhu. "EFL Adult Learners' Perceptions of Interaction and Their Attitudes Towards Learning English Online At Tesse. Io" International Journal on Studies in English Language and Literature (IJSELL), vol 8, no. 8, 2020, pp. 13-24. doi: https://doi.org/10.20431/23473134.0808003.

Copyright: (C) 2020 Authors. This is an open-access article distributed under the terms of the Creative Commons Attribution License, which permits unrestricted use, distribution, and reproduction in any medium, provided the original author and source are credited. 